\title{
The Clinical Correlation between Anterior Inferior Cerebellar Artery and Sudden Sensorineural Hearing Loss
}

\author{
Young Soo Kim ${ }^{1}$, Sung Won Choi ${ }^{1}$, Young Ki Woo ${ }^{1}$, Bo Sung Jeon ${ }^{1}$, Min Han Kim ${ }^{1}$, \\ Deok Hwan $\mathrm{Chi}^{2}$, Si-Youn Song ${ }^{1}$, Yong-Dae Kim ${ }^{1}$ and Chang Hoon Bae ${ }^{1}$ \\ ${ }^{I}$ Department of Otorhinolaryngology-Head and Neck Surgery, College of Medicine, Yeungnam University, Daegu; and \\ ${ }^{2}$ Department of Otolaryngology-Head and Neck Surgery, Gumi CHA Hospital, College of Medicine, CHA University, Gumi, Korea
}

\section{전하소뇌동맥 혈관 고리와 돌발성 감각신경성 난청과의 임상적 관련성}

\author{
김영수 ${ }^{1} \cdot$ 최성원 $^{1} \cdot$ 우영기 $^{1} \cdot$ 전보성 ${ }^{1} \cdot$ 김민한 $^{1} \cdot$ 지덕환 $^{2} \cdot$ 송시연 $^{1} \cdot$ 김용대 $^{1} \cdot$ 배창훈 $^{1}$ \\ 영남대학교 의과대학 이비인후-두경부외과학교실, ${ }^{1}$ 차의과학대학교 구미차병원 이비인후-두경부외과학교실 ${ }^{2}$
}

\author{
Received March 23, 2009 \\ Revised June 17, 2009 \\ Accepted June 23, 2009 \\ Address for correspondence \\ Chang Hoon Bae, MD \\ Department of Otorhinolaryngology- \\ Head and Neck Surgery, \\ College of Medicine, \\ Yeungnam University, \\ 317-1 Daemyeong 5-dong, Nam-gu, \\ Daegu 705-717, Korea \\ Tel $+82-53-620-3784$ \\ Fax +82-53-628-7884 \\ E-mail baich@med.yu.ac.kr
}

Background and Objectives The influence of anterior inferior cerebellar artery (AICA) loop on sudden sensorineural hearing loss (SSHL) remains controversial. The objective of this study was to evaluate the correlation between the anatomical type of AICA loop and SSHL.

Subjects and Method We reviewed the medical records of 69 ears from 60 patients with SSHL between January 2005 and April 2008, retrospectively. AICA loops were classified according to the Chavda classification method by magnetic resonance imaging. According to the extension depth of the loop in the internal auditory canal, it was classified as type I, II and III. The loop was classified as S (small diameter) and L (large diameter) by comparing the thickness of the loop with adjacent facial nerves.

Results The predominant type of AICA loop was type I (68.1\%) and type S (78.3\%). There was no significant correlation between the pretreatment hearing level, extension depth and diameter. There was also no significant correlation between the rate of hearing recovery by Siegel's criteria and diameter. However, there was significant correlation between the rate of hearing recovery by Siegel's criteria and the types of the extension depth $(p<0.05)$. The ears with type II and III of AICA loop presented higher rates of hearing recovery by Siegel's criteria than those with type I.

Conclusion This study suggests that the type II and III of AICA loop may be considered a good prognostic factor in SSHL.

Korean J Otorhinolaryngol-Head Neck Surg 2009;52:660-4

\section{서 론}

돌발성 감각신경성 난청은 급격히 발생하는 청력소실을 특 징으로 하는 이비인후과적 응급질환으로서, 발병률은 10 만 명당 5 20명으로 임상 영역에서 드물지 않게 볼 수 있는 질 환이다. ${ }^{1)}$ 발생 기전은 아직 명확히 규명되어 있지 않지만 하 나의 원인에 의한 질병이 아니라 발생 가능한 여러 기전으로 발생된다고 알려져 있다. 즉, 내이의 바이러스 감염과 혈관장 애, 와우막 파열, 자가면역질환 등에 의해 와우의 손상으로
나타나는 결과로 생각되며, 그리고 간혹 청신경 종양이나 메 니에르병 등의 기저질환이 원인이 되기도 한다. ${ }^{2,3)}$

혈관장애로 인한 돌발성 감각신경성 난청의 발생은 내이 의 혈류 공급이 전하소뇌동맥(anterior inferior cerebellar artery, AICA)에 의해 이루어지므로, 전하소뇌동맥의 경색 에 의해 돌발성 감각신경성난청이 발생할 수 있다. 전하소뇌 동맥의 경색의 원인은 분지 죽상경화증(branch atherosclerosis) 과 관련되어 임상적으로 전하소뇌동맥 영역의 혈관의 폐색으로 인한 특징적인 뇌교와 소뇌 증상이 나타나는 경우와 
전하소뇌동맥의 폐색 없이 뇌저동맥(basilar artery)의 협착 이나 혈전으로 인한 전하소뇌동맥 플러스 증후군으로 크게 나눌 수 있다.,5) 또한 전하소뇌동맥 혈관 고리(AICA loop) 가 전정와우신경(vestibulocochlear nerve)을 압박하거나 접촉하여 감각신경성 난청과 이명, 어지럼증이 발생할 수 있으며, 이를 전정와우신경 압박 증후군(cochleovestibular nerve compression syndrome)이라 한다. ${ }^{6}$ 그러나 전하 소뇌동맥 혈관 고리 형태에 따른 돌발성 감각신경성 난청과 의 임상적 관련성에 대한 국내 연구는 없었다.

이에 본 연구는 돌발성 감각신경성 난청 환자에서 전하소 뇌동맥 혈관 고리의 위치와 직경을 분류하고, 이에 따른 진 단 당시의 난청 정도와 발병 2개월 후 평가한 치료성적과의 관련성에 대하여 알아보았다.

\section{대상 및 방법}

2005년 1월부터 2008년 4월까지 발병 후 2주 이내에 돌 발성 감각신경성 난청으로 진단받고 치료 중에 내이도 자기 공명영상촬영(Philips Intera 1.5T, Netherlands)을 시행 한 환자 중에 자기공명영상촬영상 뇌병변 및 혈관장애가 없는 66명 69귀에 대해 전하소뇌동맥 혈관 고리 형태를 분 류하여, 혈관 고리의 형태에 따라 돌발성 감각신경성 난청 의 임상양상과 치료성적의 차이에 대해 후향적 조사를 하 였다.

혈관 고리가 형성되는 위치는 Chavda 분류법 ${ }^{7)}$ 에 따라 혈 관 고리가 내이도 안으로 들어가지 않고 소뇌교각에 국한되 어 있는 경우를 I형, 내이도 안으로 들어갔으나 내이도 전체 길이의 $50 \%$ 미만에 걸쳐 있는 경우를 II형, 내이도 전체 길
이의 $50 \%$ 이상 진입하여 고리를 형성하는 경우를 III형으로 분류하였고(Fig. 1), 혈관 고리의 직경을 인접한 안면신경 의 직경과 비교하여 같거나 작을 경우 $\mathrm{S}(\mathrm{small})$, 안면신경 보다 클 경우 L(large)로 분류하였다.

돌발성 감각신경성 난청 환자의 치료는 경구 스테로이드 투여, 경구 혈관 확장제 투여, 항산화제 투여, 성상신경절 차 단술 및 절대 안정, 저염식의 보존적 치료를 동일하게 시행 하였다.

돌발성 감각신경성 난청 환자에서 진단받은 시점의 난청 정도와 발병 2 개월 후 평가한 난청 정도는 순음청력검사에서 0.5 (a), 1(b), 2(c), 3(d) kHz의 네 주파수의 기도 청력역 치를 4 분법 $[(\mathrm{a}+\mathrm{b}+\mathrm{c}+\mathrm{d}) / 4]$ 으로 계산한 후 평균치를 이용 하여, 경도(mild, 26.6 40 dB), 중등도(moderate, 40 $55 \mathrm{~dB}$ ), 중등고도 (moderately severe, $55 \sim 70 \mathrm{~dB}$ ), 고도 (severe, 70 90 dB), 그리고 농(profound, $90 \mathrm{~dB}$ 이상) 으로 5단계로 나누어 평가하였다. 청력 회복 정도는 발병 후 2 개월째 시행한 동일한 순음청력검사를 통해 Siegel's criteria $^{8)}$ 따라 4 단계로 평가하였다. 혈관 고리 유형 및 직경에 따른 돌발성 감각신경성 난청의 정도 및 회복 정도에 대한 통계분석은 Fisher's exact test를 이용하였다. 통계분석 프 로그램은 SPSS(Statistical Package for Social Science) V13.0을 이용하였고 유의수준은 0.05로 하였다.

\section{결 과}

66명의 평균 연령은 46.3세였으며 남녀 비는 $1: 1$ 이었으 며, 돌발성 감각신경성 난청의 부위가 우측이 32 명, 좌측이 31 명, 양측인 경우가 3 명이었다.
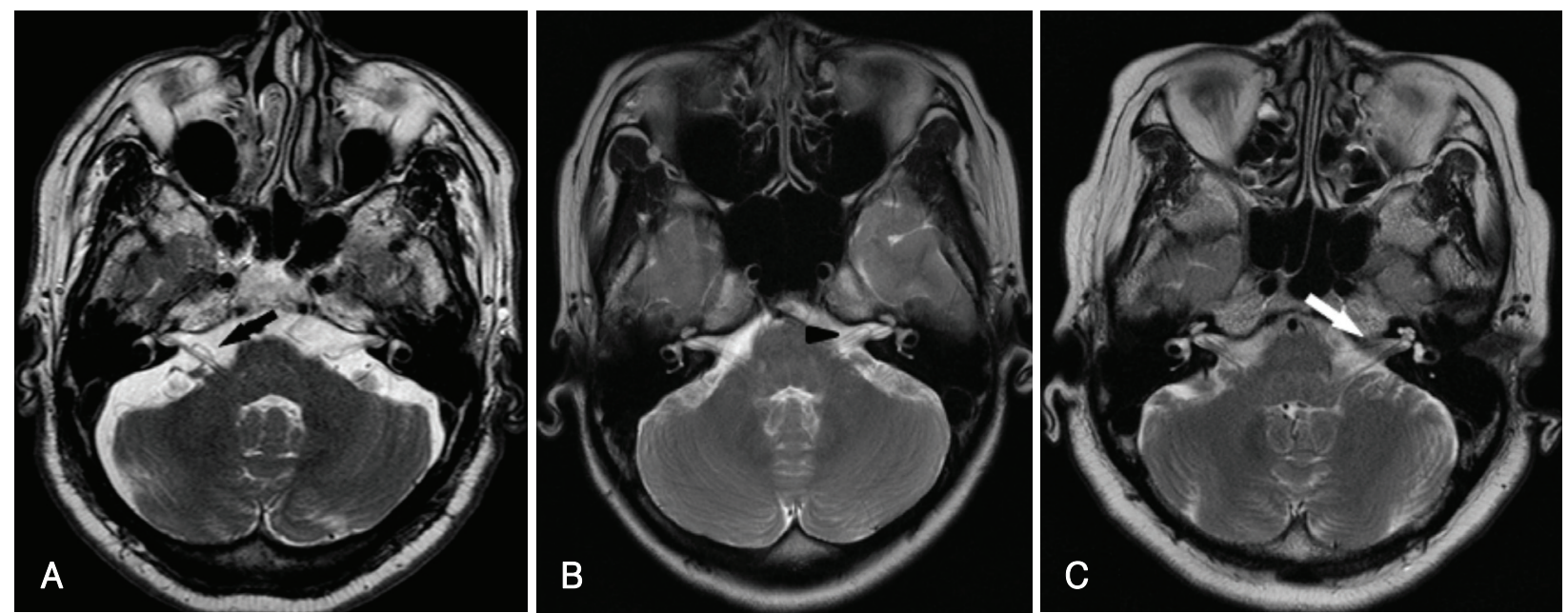

Fig. 1. Typical 3 types of AICA loop according to their extension depth in the IAC. Type I is AICA loop lying within the CPA but not entering the IAC (black arrow) (A). Type II is AICA loop entering the IAC but not extending more than $50 \%$ of the length of the IAC (black arrowhead) (B). Type III is AICA loop extending into more than $50 \%$ of the IAC (white arrow) (C). AICA: anterior inferior cerebellar artery, IAC: internal auditory canal, CPA: cerebellopontine angle. 
Table 1. Number of each classified type of AICA loops*

\begin{tabular}{lcccc}
\hline & Type I & Type II & Type III & Total (\%) \\
\hline Small diameter & $36(76.6)$ & $16(80.0)$ & $2(50.0)$ & 54 ( 78.3$)$ \\
Large diameter & $11(23.4)$ & $4(20.0)$ & $0(0.0)$ & $15(21.7)$ \\
\hline Total (\%) & $47(100.0)$ & $20(100.0)$ & $2(100.0)$ & $69(100.0)$ \\
\hline *AICA loops were classified by Chavda classification on magnetic \\
resonance imaging. AlCA: anterior inferior cerebellar artery
\end{tabular}

Table 2. Rate of subjects with initial PTA grades according to the types of AICA loop classified by the extension depth*

\begin{tabular}{lccccc}
\hline Initial PTA grade & Type I & Type II & Type III & Total (\%) \\
\hline Mild & $3(6.4)$ & $1(5.0)$ & $0(0.0)$ & $4(5.8)$ \\
Moderate & $7(14.9)$ & $1(5.0)$ & $0(0.0)$ & $8(11.6)$ \\
$\begin{array}{l}\text { Moderately } \\
\text { severe }\end{array}$ & $12(25.5)$ & $2(10.0)$ & $0(0.0)$ & $14(20.3)$ \\
Severe & $7(14.9)$ & $5(25.0)$ & $2(100.0)$ & $14(20.3)$ \\
Profound & $18(38.3)$ & $11(55.0)$ & $0(0.0)$ & $29(42.0)$ \\
\hline Total $(\%)$ & $47(100.0)$ & $20(100.0)$ & $2(100.0)$ & $69(100.0)$
\end{tabular}

*AICA loop was classified by Chavda classification on magnetic resonance imaging. PTA: pure tone audiometry, AICA: anterior inferior cerebellar artery

Table 3. The recovery rate by Siegel's criteria grades according to the types of AICA loop classified by the extension depth*

\begin{tabular}{|c|c|c|c|c|}
\hline Siegel's criteria & Type I & Type ॥ & Type III & Total (\%) \\
\hline $\begin{array}{l}\text { Complete } \\
\text { recovery }\end{array}$ & $5(10.6)$ & $6(30.0)$ & $1(50.0)$ & $12(17.4)$ \\
\hline Partial recovery & $2(4.3)$ & $3(15.0)$ & $0(0.0)$ & $5(7.3)$ \\
\hline Slight recovery & $10(21.3)$ & $7(35.0)$ & $0(0.0)$ & $17(24.6)$ \\
\hline No improvement & $30($ ( 63.8) & $4(20.0)$ & $1(50.0)$ & $35(50.7)$ \\
\hline Total (\%) & $47(100.0)$ & $20(100.0)$ & $2(100.0)$ & $69(100.0)$ \\
\hline
\end{tabular}

\section{전하소뇌동맥 혈관 고리의 위치}

69 귀에 대한 내이도 자기공명영상촬영의 분석 결과 전하 소뇌동맥 혈관 고리의 위치가 I형의 경우 $68.1 \%$ 로 가장 높 았고, II형 29.0\%, III형 2.9\% 순이었다(Table 1). 돌발성 감각신경성 난청으로 진단받은 시점의 난청 정도와 전하소뇌 동맥 혈관 고리의 위치와의 상호관련성은 없었다(Table 2). 그러나 발병 후 2개월째 Siegel's criteria로 평가한 청력 회 복 정도와 전하소뇌동맥 혈관 고리의 위치 유형과의 상호관 련성은 통계적 유의성을 보였으며 $(p<0.05)$, 발병 후 2개월 째 Siegel's criteria로 평가한 경도 증진(slight improve) 이상의 청력 회복 정도는 혈관 고리 I형인 $36.2 \%$, II형이 $75.0 \%$, III형이 $50.0 \%$ 로, II형과 III형이 I형에 비해 청력 회 복 정도가 높았다(Table 3 ).

\section{전하소뇌동맥 혈관 고리의 직경}

전하소뇌동맥 혈관 고리의 직경별 유형은 $\mathrm{S}$ 형의 경우 $78.3 \%$ 와 L형 $21.7 \%$ 였다(Table 1). 전하소뇌동맥 혈관 고
Table 4. Rate of subjects with initial PTA grades according to the types of AICA loop classified by diameter*

\begin{tabular}{lccr}
\hline \multicolumn{1}{c}{$\begin{array}{c}\text { Initial PTA } \\
\text { grade }\end{array}$} & \multicolumn{2}{c}{ AlCA loop } & \multirow{2}{*}{ Total (\%) } \\
\cline { 2 - 3 } & Small diameter & Large diameter & \\
\hline Mild & $4(7.4)$ & $0(0.0)$ & $4(5.8)$ \\
Moderate & $6(11.1)$ & $2(13.3)$ & $8(11.6)$ \\
$\begin{array}{l}\text { Moderately } \\
\text { severe }\end{array}$ & $10(18.5)$ & $4(26.7)$ & $14(20.3)$ \\
$\begin{array}{l}\text { Severe } \\
\text { Profound }\end{array}$ & $12(22.2)$ & $2(13.3)$ & $14(20.3)$ \\
\hline Total $(\%)$ & $54(100.0)$ & $15(100.0)$ & $69(100.0)$ \\
\hline
\end{tabular}

*AICA loop was classified by Chavda classification on magnetic resonance imaging. PTA: pure tone audiometry, AICA: anterior inferior cerebellar artery

Table 5. The recovery rate by Siegel's criteria grades according to the types of AICA loop classified by the diameter*

\begin{tabular}{lccr}
\hline \multirow{2}{*}{ Siegel's criteria } & \multicolumn{2}{c}{ AlCA loop } & \multirow{2}{*}{ Total (\%) } \\
\cline { 2 - 3 } $\begin{array}{l}\text { Complete } \\
\text { recovery }\end{array}$ & $10(18.5)$ & $2(13.3)$ & $12(17.4)$ \\
Partial recovery & $5(9.3)$ & $0(0.0)$ & $5(7.3)$ \\
Slight recovery & $12(22.2)$ & $5(33.3)$ & $17(24.6)$ \\
No improvement & $27(50.0)$ & $8(53.3)$ & $35(50.7)$ \\
\hline Total (\%) & $54(100.0)$ & $15(100.0)$ & $69(100.0)$ \\
\hline
\end{tabular}

*AICA loop was classified by Chavda classification on magnetic resonance imaging. AICA: anterior inferior cerebellar artery

리의 직경에 따른 $\mathrm{S}$ 형과 $\mathrm{L}$ 형에서 진단받은 시점의 난청 정 도와 발병 후 2개월째 Siegel's criteria로 평가한 청력 회복 정도와의 상호관련성은 통계적 유의성이 없었다(Table 4 and 5).

\section{고 찰}

돌발성 감각신경성 난청의 원인에 관해서는 아직 확실히 밝혀진 바는 없으나 바이러스 감염과 외림프 누공, 자가 면 역질환 및 혈관성 요인 등으로 생각된다. 이 중 혈관성 요인 으로는 전하소뇌동맥 경색에 의해 발생한 돌발성 감각신경 성 난청과 전하소뇌동맥 혈관 고리에 의한 전정와우신경의 압박에 의해 발생한 돌발성 감각신경성 난청에 대해서 보고 되고 있다. ${ }^{3,699)}$ 그 기전으로는 내이의 신경절세포(ganglion cell) 와 신경세포의 혈류 공급은 전하소뇌동맥에서 분지된 내이동맥(internal auditory artery)을 통하여 총와우동맥 (common cochlear artery) 과 전전정동맥 (anterior vestibular artery)으로 이루어지므로, ${ }^{10)}$ 전하소뇌동맥의 경색으 로 인하여 난청과 어지럼증이 유발된다. 또한 전하소뇌동맥 혈관 고리는 고리의 모양이 길게 꺽이면서 내이도 안으로 들 어가는 경우에는 제한된 소뇌교각조의 공간에서 전정와우신 경과 접촉하거나 압박하여 난청과 이명, 어지럼증이 발생한 
다. 이를 전정와우신경 압박 증후군이라고 하고, 진단은 전정 와우 증상이 있으면서 청각유발전위, 전기안진도검사에 이상 소견을 보이며 모든 내과적 및 외과적 치료에 실패하는 경우, 자기공명영상 등 방사선학적 영상에서 혈관 고리가 신경에 접촉되는 소견이 있으면 이 증후군을 의심해 볼 수 있다. ${ }^{11)}$ 그러나 국내에서는 전하소뇌동맥 혈관의 경색과 전하소뇌동 맥 플러스 증후군, 전정와우신경 압박 증후군에 의해 발생한 돌발성 감각신경성 난청의 증례들 3.5 만 보고되고 있으며, 본 연구와 같이 전하소뇌동맥 혈관과 돌발성 감각신경성 난청 에 대한 임상적 연구는 아직까지 보고된 바가 없다.

전하소뇌동맥 혈관 고리의 다양한 해부학적 형태에 대한 연구는 1945년부터 시작되어 1990년까지는 사체 해부를 통해 연구되었으나 1990년대 후반부터는 발달된 영상 술기 의 영향으로 주로 자기공명영상촬영을 통해 연구가 이루어 지고 있다. ${ }^{7,12-18)}$ 사체 해부 결과에 따르면 소뇌교각조에 고 리가 위치한 경우가 $33 \sim 56 \%$, 내이공에 인접한 경우는 20 $34 \%$, 내이도 내부에 있는 경우는 $14 \sim 40 \%$ 로 보고되고 있 으나, ${ }^{12-15)}$ 자기공명영상촬영으로 연구한 결과는 소뇌교각 조 63 78\%, 내이공 12 29\%, 내이도 8 10\%로 소뇌교 각조에서 고리를 형성하는 경우가 훨씬 우세한 것으로 보고 되어 사체 해부 연구와 차이를 보이고 있다. 7.16-18) 본 연구에 서도 내이도 자기공명영상촬영을 통해 전하소뇌동맥 혈관 고 리 형태를 연구하였으며 Chavda 분류에 따라 I형 $68.1 \%$, II형 $29.0 \%$, III형 $2.9 \%$ 순으로 III형은 비율은 낮았으나 I 형과 II형의 비율은 다른 자기공명영상촬영으로 시행한 연구 와 비슷하였다.

McDermott 등근 거-dimensional Fourier transformation constructive interference in steady state(3DFTCISS) 자기공명영상촬영을 이용한 연구에서 혈관 고리가 내 이도 안으로 진입하는 Chavda II형과 III형이 I형에 비해 난 청이 많았고, 혈관의 두께는 와우 증상과 유의한 관련이 없 다고 하였다. 이를 본 연구 결과와 비교하면, 혈관 고리의 위치별 유형 II형과 III형의 경우 내이도 안으로 혈관 고리가 들어와 있는 경우로 돌발성 난청을 일으키는 원인이 혈관성 원인 즉, 혈관 고리에 의한 전정와우신경 압박 증후군에 의 한 것으로 생각할 수도 있다.

전정와우신경 압박 증후군의 내과적 치료로는 주로 신경 안정제, 혈관 확장제, 혈액순환 개선제 등을 사용하며 외과적 치료는 약물에 반응하지 않는 $10 \%$ 정도의 환자를 대상으 로 미세혈관감압술을 시행하고 있다. ${ }^{19)}$ 본 연구에서 Chavda I형보다 전정와우신경 압박이 발생할 수 있는 II형과 III형에 서 청력 회복 정도가 높은 이유는 돌발성 감각신경성 난청 환자의 치료가 전정와우신경 압박 증후군의 내과적 치료와
유사한 신경안정제, 혈관 확장제, 혈액순환 개선제, 성상신경 차단술을 시행하였기 때문일 것으로 생각된다.

돌발성 감각신경성 난청의 예후에 영향을 미치는 인자들 로는 연령과 발병 후 치료까지의 기간, 초기 청력 소실의 정 도, 초기 청력도의 모양, 어지럼의 동반 여부 등이 있다. 좋 은 예후인자로는 고령이 아닌 경우와 조기 치료, 초기 청력 손실이 경한 경우, 초기 청력도의 모양이 수평형과 상승형일 경우, 어지럼이 동반되지 않은 경우이며, ${ }^{20)}$ 본 연구 결과를 통해 돌발성 감각신경성 난청에서 치료 후 청력 회복 정도 가 높은 Chavda II형과 III형도 좋은 예후인자의 하나로 생각할 수도 있다.

본 연구에서는 전하소뇌동맥 혈관 고리의 위치와 청력 회 복 정도를 제외한 전하소뇌동맥 혈관 고리 형태에 따른 돌발 성 감각신경성 난청과 임상적 관련성을 찾을 수가 없었는데, 이는 전체 대상군의 수가 적었고 혈관 고리 III형이 2 귀 밖 에 없었기 때문인 것으로 생각된다. 그러므로 전하소뇌동맥 혈관 고리 형태에 따른 돌발성 감각신경성 난청과의 임상적 관련성을 보다 명확하게 알기 위해서는 돌발성 감각신경성 난청으로 진단받은 환자 중 내이도 자기공명영상 촬영을 시 행한 일부 환자를 대상으로 한 후향적인 연구보다는 더 많 은 대상군으로 전향적인 연구가 필요하다.

\section{REFERENCES}

1) Byl FM Jr. Sudden hearing loss: eight years' experience and suggested prognostic table. Laryngoscope 1984;94 (5 pt 1):647-61.

2) Yim KC, Park KY, Lee KI, Chun KD. Clinical analysis of sudden hearing loss. Korean J Otolaryngol-Head Neck Surg 1995;38 (6) :83441.

3) Kim JP, Cheon JH, Sung JH, Jeong JH. Sudden deafness caused by acute anterior inferior cerebellar artery infarction: a case report. Korean J Otolaryngol-Head Neck Surg 2000;43 (3) :329-31.

4) Amarenco P, Rosengart A, DeWitt LD, Pessin MS, Caplan LR. Anterior inferior cerebellar artery territory infarcts. Mechanisms and clinical features. Arch Neurol 1993;50 (2):154-61.

5) Baek MJ, Choi JB. A case of bilateral sudden hearing loss caused by right anterior inferior cerebellar artery plus syndrome and left anterior inferior cerebellar artery infarction. Korean J Otolaryngol-Head Neck Surg 2005;48 (6):810-2.

6) Jeon EJ, Park YS, Lee JW, Lee SK, Chang KH, Lee JH, et al. Correlation between anterior inferior cerebellar artery loop and otologic symptoms. Korean J Otolaryngol-Head Neck Surg 2006;49 (6) :604-10.

7) McDermott AL, Dutt SN, Irving RM, Pahor AL, Chavda SV. Anterior inferior cerebellar artery syndrome: fact or fiction. Clin Otolaryngol Allied Sci 2003;28(2):75-80.

8) Siegel LG. The treatment of idiopathic sudden sensorineural hearing loss. Otolaryngol Clin North Am 1975;8 (2):467-73.

9) Son EJ, Bang JH, Kang JG. Anterior inferior cerebellar artery infarction presenting with sudden hearing loss and vertigo. Laryngoscope 2007;117 (3) :556-8.

10) Naidich TP, Kricheff II, George AE, Lin JP. The normal anterior inferior cerebellar artery. Anatomic-radiographic correlation with emphasis on the lateral projection. Radiology 1976;119(2):355-73.

11) McCabe BF, Gantz BJ. Vascular loop as a cause of incapacitating diz- 
ziness. Am J Otol 1989;10 (2) :117-20.

12) Mazzoni A, Hansen CC. Surgical anatomy of the arteries of the internal auditory canal. Arch Otolaryngol 1970;91 (2):128-35.

13) Martin RG, Grant JL, Peace D, Theiss C, Rhoton AL Jr. Microsurgical relationships of the anterior inferior cerebellar artery and the facial-vestibulocochlear nerve complex. Neurosurgery 1980;6(5):483-507.

14) Ouaknine GE. The arterial loops of the pontocerebellar angle. Microsurgical anatomy and pathological consideration. Adv Otorhinolaryngol 1982;28:121-38.

15) Kim HN, Kim YH, Park IY, Kim GR, Chung IH. Variability of the surgical anatomy of the neurovascular complex of the cerebellopontine angle. Ann Otol Rhinol Laryngol 1990;99 (4 pt 1) :288-96.

16) Chung EC, Choi HY, Lee JS, Ko EJ, Lee MS. Constructive interference in steady state (CISS) 3DFT MR imaging of the inner ear and adjacent structures. J Korean Radiol Soc 1997;36 (3) :385-91.

17) Makins AE, Nikolopoulos TP, Ludman C, O’Donoghue GM. Is there a correlation between vascular loops and unilateral auditory symptoms? Laryngoscope 1998;108 (11 Pt 1):1739-42.

18) Yurtseven $T$, Savaş R, Koçak A, Turhan T, Aktaş EO, Ișlekel S. Relationship between anterior inferior cerebellar artery and facial-vestibulocochlear nerve complex: an anatomical and magnetic resonance images correlation study. Minim Invasive Neurosurg 2004;47 (5) :306-11.

19) Møller MB, Møller AR, Jannetta PJ, Sekhar L. Diagnosis and surgical treatment of disabling positional vertigo. J Neurosurg 1986;64 (1):21-8.

20) Lee JK, Seo DJ, Cho HH, Cho Y, Kim HJ, Cho YB. A study on the hearing recovery patterns in sudden sensorineural hearing loss patients. Korean J Otolaryngol-Head Neck Surg 2002;45 (7) :656-61. 